\title{
Influence of Nitrogen Application Time on Nitrogen Absorption, Partitioning, and Yield of Pecan
}

\author{
Laura Elisa Acuña-Maldonado, ${ }^{1}$ Michael W. Smith, ${ }^{2}$ Niels O. Maness, ${ }^{3}$ Becky S. Cheary, ${ }^{4}$ and \\ Becky L. Carroll ${ }^{4}$ \\ Department of Horticulture and Landscape Architecture, Oklahoma State University, Stillwater, OK \\ 74078
}

\author{
Gordon V. Johnson² \\ Department of Plant and Soil Science, Oklahoma State University, Stillwater, OK 74078
}

Additional Index words. Carya illinoinensis, nitrate, total N, Kjeldahl, organic N

\begin{abstract}
Nitrogen was applied to mature pecan (Carya illinoinensis Wangenh. C. Koch.) trees annually as a single application at $125 \mathrm{~kg} \cdot \mathrm{ha}^{-1} \mathrm{~N}$ in March or as a split application with $60 \%\left(75 \mathrm{~kg} \cdot \mathrm{ha}^{-1} \mathrm{~N}\right)$ applied in March and the remaining $40 \%\left(50 \mathrm{~kg} \cdot \mathrm{ha}^{-1} \mathrm{~N}\right)$ applied during the first week of October. Nitrogen treatment did not affect yield, and had little effect on the amount of $\mathrm{N}$ absorbed. Nitrogen absorption was greater between budbreak and the end of shoot expansion than at other times of the year. Substantial amounts of $\mathrm{N}$ were also absorbed between leaf fall and budbreak. Little $\mathrm{N}$ was absorbed between the end of shoot expansion and leaf fall, or tree $\mathrm{N}$ losses met or exceeded $\mathrm{N}$ absorption. Pistillate flowers and fruit accounted for a small portion of the tree's $N ; \approx 0.6 \%$ at anthesis and $4 \%$ at harvest. The leaves contained $\approx 25 \%$ of the tree's $N$ in May and $\approx 17 \%$ when killed by freezing temperatures in November. Leaves appeared to contribute little to the tree's stored $\mathrm{N}$ reserves. Roots $\geq 1 \mathrm{~cm}$ diameter were the largest site of $\mathrm{N}$ storage during the winter. Stored $\mathrm{N}$ reserves in the perennial parts of the tree averaged $13 \%$ of the tree's total $\mathrm{N}$ over a three year period. Current year's $\mathrm{N}$ absorption was inversely related to the amount of stored $\mathrm{N}$, but was not related to the current or previous year's crop load.
\end{abstract}

Irregular bearing is a major problem in pecan (Carya illinoinensis Wangenh. C. Koch.) (Wood, 1993), as well as in other fruit crops (Monselise and Goldschmidt, 1982). Studies suggest the amount of nonstructural carbohydrates stored during winter may be closely linked to the flowering potential of pecan (Lockwood and Sparks, 1978; Smith and Waugh, 1938; Wood, 1988, 1989, 1991, 1995; Worley, 1979a, 1979b). Nitrogen depletion by large crops occurs in pistachio (Pistacia vera L.) (Brown et al., 1995; Rosecrance et al., 1998; Weinbaum et al., 1994a), citrus (Citrus reticulata Blanco) (Golomb and Goldschmidt, 1987) and prune (Prunus domestica L.) (Weinbaum et al., 1994b). Depleted $\mathrm{N}$ reserves by large fruit crops may inhibit pecan pistillate flower induction or cause greater flower abortion.

One method to alleviate such shortages is to increase winter/ spring fertilizer rates. However, when available $\mathrm{N}$ exceeds short term demand, tree absorption efficiency is low and nitrates may be leached into the ground water (Weinbaum et al., 1992). An alternative is to apply $\mathrm{N}$ when tree need is high, since $\mathrm{NO}_{3}$ absorption appears to be demand-driven (Rosecrance et al., 1998; Weinbaum et al., 1994a), and is regulated by the flow of $\mathrm{N}$ in the vascular system (Cooper and Clarkson, 1989; Imsande and Touraine, 1994; Lee et al., 1992). Nitrogen applied when demand and consequently, absorption efficiency is high should allow lower $\mathrm{N}$ rates to achieve the same results as incorrectly timed higher rates.

There is little information regarding the periodicity of $\mathrm{N}$ uptake in mature pecan trees and the effects of fertilizer applica-

Received for publication 8 July 2002. Accepted for publication 4 Nov. 2002. Approved for publication by the Oklahoma Agricultural Experiment Station. This research was funded by the Oklahoma Agricultural Experiment Station and grants from the Samuel Roberts Noble Foundation and the Oklahoma Center for the Advancement of Science and Technology.

${ }^{1}$ Graduate student.

${ }^{2}$ Regents professor; e-mail mws@okstate.edu.

${ }^{3}$ Professor.

${ }^{4}$ Research technician. tion time on pecan performance. One study reported that $\mathrm{N}$ application time did not affect pecan yield; however, nut quality was reduced when the $\mathrm{N}$ application was split between spring and summer (Hunter and Lewis, 1942). Hunter and Lewis (1492) speculated that growth stimulated by the summer application competed with developing fruit for available carbohydrates, thus reducing quality. Another study found that yield of one cultivar was increased 4 of 7 years when $\mathrm{N}$ was applied in October rather than March, but yield of another cultivar was not affected (Smith et al., 1995). October $\mathrm{N}$ application did not affect nut quality or stimulate shoot growth. In pear (Pyrus communis L.), N applied during the summer or fall was absorbed and assimilated more efficiently than spring applied $\mathrm{N}$, resulting in accelerated flower development and increased fruit set (Taylor et al., 1975). Fall applied $\mathrm{N}$ delayed fall leaf senescence of pear, a characteristic positively associated with increased pecan female flower production (Hinrichs, 1962; Worley, 1979a). In apple (Malus x domestica Borkh.), flower buds are initiated during late summer for next year's crop. A consistent response reported in apple was summer (July or August) or fall (September or October) applied N accelerated flower development, decreased flower abortion, and extended pistil receptivity, resulting in more fruit set during the subsequent season (Delap, 1967; Hill-Cottingham, 1963; HillCottingham and Williams, 1967; Williams, 1963, 1965).

We hypothesized that $\mathrm{N}$ application split between March and October would be more efficiently absorbed than when applied as a single application in March. We speculated that $\mathrm{N}$ demand should be high beginning at budbreak, shortly after the March application, and again in October near crop maturity. Also, October applied $\mathrm{N}$ should prevent a $\mathrm{N}$ shortage at a time when floral induction may be reversed or developing flowers (Wetzstein and Sparks, 1983) aborted, thus reducing irregular bearing. In this study we had three objectives. The first was to determine the effect of a single $\mathrm{N}$ application applied in March vs. an application split between March and October on yield and $\mathrm{N}$ absorption. The second objective was to characterize the periodicity of $\mathrm{N}$ absorp- 
tion, and the third was to elucidate seasonal $\mathrm{N}$ partitioning in pecan.

\section{Materials and Methods}

Ten 15-year-old 'Maramec' trees growing in a Teller sandy loam (fine-loamy, mixed, active, thermic Udic Argiustoll) at the Fruit and Pecan Research Station near Perkins, Okla. were selected based on uniformity of size, vigor and location within the orchard. Trees were spaced $12.2 \times 12.2 \mathrm{~m}$ and were $9.3 \pm 1.2 \mathrm{~m}$ tall with $29 \pm 3 \mathrm{~cm}$ diameter trunks measured $1.4 \mathrm{~m}$ above the ground at the start of the study. A 7.3-m-wide weed-free area was maintained the entire row length with selected herbicides. Trees were drip irrigated based on the model developed by Worthington (Worthington and Stein, 1993), except when a traveling gun was used following fertilizer application to incorporate the surfaceapplied nitrogen. Pest management was according to Oklahoma Cooperative Extension Service recommendations (Smith and McCraw, 1998; von Broembsen et al., 1999).

Treatments were a single $\mathrm{N}$ application annually during the second week of March $\left(125 \mathrm{~kg} \cdot \mathrm{ha}^{-1} \mathrm{~N}\right)(\approx 3$ weeks before budbreak $)$ or a split application with $60 \%\left(75 \mathrm{~kg} \cdot \mathrm{ha}^{-1} \mathrm{~N}\right)$ applied in March followed by $40 \%\left(50 \mathrm{~kg} \cdot \mathrm{ha}^{-1} \mathrm{~N}\right)$ during the first week in October $(\approx 2$ weeks before $50 \%$ shuck split). Fertilizer was uniformly spread over the entire area allotted to each tree $(12.2 \times 12.2 \mathrm{~m}$ plus border trees) with a hand-push spreader. All trees in the study were bordered by trees receiving like treatments. Ammonium nitrate was used during 1997 and 1998, and urea was used during the remainder of the study due to lack of availability of ammonium nitrate following the Oklahoma City bombing. The experimental design was a randomized complete block design with five single-tree replications.

Tissue SAMPLES. Samples included roots $<1 \mathrm{~cm}$ diameter and $\geq 1 \mathrm{~cm}$ diameter that were excavated with a backhoe. The root samples were collected from each tree in an area $\approx 1 \mathrm{~m}$ wide, $2 \mathrm{~m}$ long and $1.5 \mathrm{~m}$ deep. A new location was chosen each time roots were sampled. Root samples were washed to remove adhering soil, dried at $70{ }^{\circ} \mathrm{C}$, then segments of the roots were cut for grinding. Samples were ground to pass a 20 -mesh screen, then 10to 20-g aliquots were stored in airtight jars until analysis.

The trunk was sampled by boring about ten 2.5 -cm holes with a spade bit $\approx 5 \mathrm{~cm}$ deep, then dividing the sample into bark and wood. The samples were collected in a vertical line on the trunk to reduce damage, then the holes were filled with mortar mix. Samples were dried and prepared for analysis as described above.

Five 1-year-old branches and ten current season shoots per tree were sampled on each date. All the branches or shoots were dried and ground and an aliquot of the ground material was stored for analysis. Leaf samples consisted of all leaves (leaflets and rachis) on five current season shoots. Five fruit clusters were collected during each sample date, with the whole pistillate flower or fruit used for analysis, except at harvest when the fruit was divided into shuck (involucre), shell (pericarp) and kernel (cotyledons and embryo). Samples were prepared as describe earlier, with a suitable aliquot stored for analysis.

SAMPLE TIME. Sample times were at stage 4 budbreak (Wetzstein and Sparks, 1983) (second to third week of April), pollination (last week of May), the third week of July, before fall fertilizer application ( 1 to 3 Oct.), immediately after the first killing freeze in the fall (11 Nov. 1997, 12 Nov. 1998, 18 Nov. 1999, and 10 Oct. 2000). Samples were also collected the third week in February during 1998 and 1999. Table and figure headings and legends reflect November as the defoliation collection time for convenience, but it should be noted that in 2000 an exceptionally early freeze occurred in October, and samples were collected then.

SAMPLE ANALYsIS. Nitrogen was analyzed by macro-Kjeldahl (organically bound N) (Horowitz, 1980). Samples were redried at $70{ }^{\circ} \mathrm{C}$ for $24 \mathrm{~h}$ before analysis, then allowed to cool to room temperature before weighing a $1 \mathrm{~g}$ sample for analysis.

Biomass estimation. Biomass of the perennial tree components was estimated using equations of King and Schnell (1972). These equations were used by Kraimer et al. (2001) to estimate pecan weight in a New Mexico study. To confirm these equations and develop an equation to estimate leaf mass, three 15-year-old 'Maramec' trees spaced $10.7 \times 10.7 \mathrm{~m}$ apart, growing on a Port silt loam (fine-silty, mixed, superactive, thermic Cumulic Haplustolls) at the Pecan Research Station near Sparks, Okla. were harvested on 16 to 23 Oct. 1998. Trees were similar in size to those in the present study. Trees were cut at the soil line and divided into fruit, leaves, current season shoots, 1-year-old branches, older branches and trunk. Roots of each tree were sampled by excavating two 51 $\mathrm{cm}$ by $5.3 \mathrm{~m}$ long (one-half the distance between trees) areas $\approx 2$ $\mathrm{m}$ deep at a right angle from the crown. The water table was $\approx 2$ $\mathrm{m}$ from the soil surface, and no roots were observed below this point. Roots were removed from the excavated soil, then divided into those $<1 \mathrm{~cm}$ and $\geq 1 \mathrm{~cm}$ in diameter. Leaves, fruit, and current season shoots were dried intact at $70^{\circ} \mathrm{C}$, and the other tree parts were mechanically chipped, then dried and weighed. A regression equation for predicting leaf mass was developed $(\mathrm{Y}=$ $0.000547 \mathrm{X}^{3.4067} ; R^{2}=0.99 ; P \geq 0.05$; where $\mathrm{Y}=$ leaf dry weight in $\mathrm{kg}$ and $\mathrm{X}=$ trunk diameter in $\mathrm{cm} 1.4 \mathrm{~m}$ above the soil line).

Six wood disks, $\approx 8 \mathrm{~cm}$ thick, were collected from destructively sampled tree trunks and branches. Outer and inner bark was removed from the disks, then the wood disks were divided into 10 equal parts from the perimeter to the center, dried, weighed, ground, and organically bound $\mathrm{N}$ determined. A regression equation was developed to predict the $\mathrm{N}$ concentration of the wood at various distances from the perimeter $\left(\mathrm{Y}=0.755 \mathrm{X}^{-0.3756} ; R^{2}=0.62\right.$; $P \geq 0.1 \%$; where $\mathrm{Y}=\% \mathrm{~N}$ and $\mathrm{X}=$ distance from the perimeter in $\%)$.

Tree weights of the three destructively sampled trees averaged $2 \%$ less than weights predicted by equations of King and Schnell (1972), indicating that tree weight was estimated with reasonable accuracy by the equations. Kraimer et al. (2001) reported that tree weights of pecan were $8.6 \%$ less than the weight estimated using King and Schnell's equations. Our tree weights may agree more closely with the calculated weights because the trees of Kraimer et al. (2001) were hedged, whereas ours were not.

Organic N ESTimates. Total $\mathrm{N}$ in each tree component was calculated by multiplying the estimated weight by the $\mathrm{N}$ concentration, except for the wood and fruit. The trunk wood weight of trees in the $\mathrm{N}$ application time study were divided into 10 equal parts, multiplied by the measured $\mathrm{N}$ concentration that was adjusted for $\mathrm{N}$ concentration change at various distances from the perimeter using the equation described above, then $\mathrm{N}$ contents summed to determine total $\mathrm{N}$ contained in the wood. Fruit mass was determined by calculating the number of fruit at harvest for each tree based on the mean fruit weight of duplicate 20 fruit samples per tree and total tree yield. The number of fruit per tree was then used to calculate fruit weight for each tree during the various sample times based on the mean fruit weight of the five fruit clusters $(\approx 20$ fruit/tree) sampled on each date. Total $\mathrm{N}$ in the fruit was then calculated from the fruit weight and $\mathrm{N}$ concentration. 
YieLd, NUT SIZE, AND KERNEL PERCENT. Total yield was measured annually, and duplicate 20 -fruit samples were collected from each tree and analyzed for weight per nut and kernel yield. In 1998, there was no harvestable yield although trees had some return bloom. Poor pollination conditions combined with underdeveloped flowers that aborted resulted in little fruit set, and depredation by pests eliminated what few fruit had set.

\section{Results}

Nitrogen ABSORPTION. There were no significant differences between $\mathrm{N}$ treatments in $\mathrm{N}$ absorbed for the year (November to the following November) in 1998 or 1999, but in 2000 trees receiving a single $\mathrm{N}$ application in March gained $293 \mathrm{~g} /$ tree while those with the nitrogen application split between March and
October lost $806 \mathrm{~g} /$ tree (Table 1). Gains in $\mathrm{N}$ from year to year reflect increased tree size, since the concentrations in the various tree components were relatively constant for the same sample date (Table 2). The primary times of $\mathrm{N}$ absorption were while the tree was dormant (November to February or November to April, i.e., leaf fall to budbreak) and April through May (budbreak through rapid shoot and leaf expansion), although there was a net $\mathrm{N}$ loss from November to April in 2000. At other times of the year there was a net loss of organic $\mathrm{N}$, except for two times between October and November. These data do not exclude the possibility that $\mathrm{N}$ was absorbed from May through November, but indicate that $\mathrm{N}$ losses usually exceeded $\mathrm{N}$ absorption. These data also suggest that some $\mathrm{N}$ was absorbed between October and November, but the amount absorbed was small relative to other times and was frequently overshadowed by $\mathrm{N}$ losses. Variable results were

Table 1. The influence of year and nitrogen treatment on changes in organically bound nitrogen.

\begin{tabular}{|c|c|c|c|c|c|c|c|c|}
\hline Year & $\begin{array}{l}\mathrm{N} \\
\text { treatment }\end{array}$ & \multicolumn{7}{|c|}{$\mathrm{N}$ gained $(+)$ or lost $(-)(\mathrm{g} /$ tree $)$} \\
\hline 1997 & Single & --- & $\begin{array}{ll}-- \\
-1\end{array}$ & --- & --- & --- & --- & 90 \\
\hline \multirow[t]{2}{*}{1998} & Single & 411 & -19 & 319 & 1749 & -421 & -104 & -250 \\
\hline & Split & 345 & $296^{*}$ & $1526^{*}$ & $753^{*}$ & -176 & -48 & -532 \\
\hline 1999 & Single & 338 & 437 & 1047 & 1155 & -451 & -236 & -192 \\
\hline 2000 & Split & $-806^{*}$ & --- & -1279 & 1869 & -434 & -464 & -166 \\
\hline \multirow[t]{2}{*}{2001} & Single & --- & --- & 760 & --- & --- & --- & --- \\
\hline & Split & --- & --- & 730 & --- & --- & --- & --- \\
\hline
\end{tabular}

${ }^{\mathrm{z}}$ Nitrogen change calculated with leaves and fruit absent.

${ }^{\mathrm{y} N i t r o g e n}$ change calculated with leaves and fruit absent in April and leaves and fruit in present in May.

${ }^{x}$ Nitrogen change calculated with leaves and fruit present on both dates.

*Means within columns and years followed by an asterisk are significantly different $(P \leq 0.05)$.

Table 2. Seasonal changes in organically bound nitrogen concentration of selected plant parts. Data are pooled over nitrogen treatments.

\begin{tabular}{|c|c|c|c|c|c|c|c|c|c|}
\hline \multirow[b]{3}{*}{ Year } & \multirow[b]{3}{*}{ Month } & \multicolumn{8}{|c|}{$\mathrm{N}$ conn $(\%$ dry wt) } \\
\hline & & \multicolumn{8}{|c|}{ Plant part } \\
\hline & & $\begin{array}{c}\text { Roots } \\
<1 \mathrm{~cm} \text { diam }\end{array}$ & $\begin{array}{c}\text { Roots } \\
\geq 1 \mathrm{~cm} \text { diam }\end{array}$ & Wood & Bark & $\begin{array}{l}\text { 1-Year-old } \\
\text { branches }\end{array}$ & $\begin{array}{l}\text { Current } \\
\text { season }\end{array}$ & Leaf & Fruit \\
\hline \multirow[t]{2}{*}{1997} & Oct & 0.94 & 1.10 & 0.56 & 0.58 & 0.65 & 0.74 & 2.01 & 0.90 \\
\hline & Nov & $1.09^{*}$ & $1.48^{*}$ & $0.32^{*}$ & $0.71^{*}$ & 0.62 & $1.01^{*}$ & 1.92 & 0.96 \\
\hline \multirow[t]{6}{*}{1998} & Feb & 1.24 & 1.46 & 0.34 & 0.69 & 0.70 & 1.01 & --- & --- \\
\hline & Apr & $1.31^{*}$ & 1.63 & $0.46^{*}$ & 0.78 & 0.59 & $1.27^{*}$ & --- & --- \\
\hline & May & 1.22 & 1.43 & $0.27^{*}$ & 0.83 & $0.79^{*}$ & $1.43^{*}$ & 2.49 & --- \\
\hline & Jul & 1.13 & $1.25^{*}$ & $0.34^{*}$ & 0.75 & 0.75 & $1.03^{*}$ & $2.29^{*}$ & --- \\
\hline & Oct & 1.16 & $1.03^{*}$ & $0.43^{*}$ & 0.75 & $0.66^{*}$ & $0.80^{*}$ & 2.28 & --- \\
\hline & Nov & 1.17 & 1.19 & $0.35^{*}$ & 0.80 & $0.85^{*}$ & $0.70^{*}$ & $1.61^{*}$ & --- \\
\hline \multirow[t]{6}{*}{1999} & Feb & 1.33 & 1.36 & 0.36 & 0.82 & 0.92 & 1.01 & --- & --- \\
\hline & Apr & 1.10 & $1.60^{*}$ & $0.41^{*}$ & 0.84 & 0.72 & $0.86^{*}$ & --- & --- \\
\hline & May & 1.18 & $1.37^{*}$ & $0.23^{*}$ & 0.83 & $1.07^{*}$ & $1.82^{*}$ & 2.58 & 2.36 \\
\hline & Jul & 1.21 & 1.27 & $0.32^{*}$ & 0.78 & $0.74^{*}$ & $1.01^{*}$ & $1.95^{*}$ & $1.25^{*}$ \\
\hline & Oct & $1.03^{*}$ & 1.30 & $0.23^{*}$ & 0.75 & 0.77 & $0.94^{*}$ & 2.01 & $0.99^{*}$ \\
\hline & Nov & 1.11 & 1.45 & $0.29^{*}$ & 0.77 & $0.84^{*}$ & 0.92 & $1.22^{*}$ & $1.14^{*}$ \\
\hline \multirow[t]{5}{*}{2000} & Apr & $1.38^{*}$ & 1.63 & 0.30 & $0.83^{*}$ & 0.82 & $1.24^{*}$ & --- & --- \\
\hline & May & $1.16^{*}$ & $1.36^{*}$ & $0.18^{*}$ & 0.81 & $1.03^{*}$ & $1.66^{*}$ & 2.50 & 2.40 \\
\hline & Jul & 1.09 & 1.14 & $0.25^{*}$ & $0.74 *$ & $0.78^{*}$ & $1.20^{*}$ & 2.47 & $1.37^{*}$ \\
\hline & Oct & $0.95^{*}$ & 1.22 & 0.25 & 0.75 & $0.71^{*}$ & $0.95^{*}$ & $2.02^{*}$ & $0.99^{*}$ \\
\hline & Nov & 1.02 & 1.18 & 0.26 & 0.72 & 0.69 & 0.88 & 1.91 & $1.14^{*}$ \\
\hline 2001 & Apr & 1.05 & $1.47^{*}$ & 0.26 & $0.79^{*}$ & 0.73 & $1.46^{*}$ & --- & --- \\
\hline
\end{tabular}

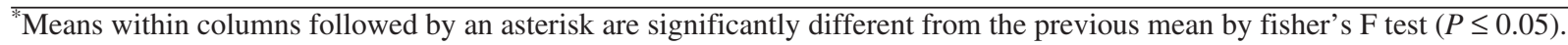




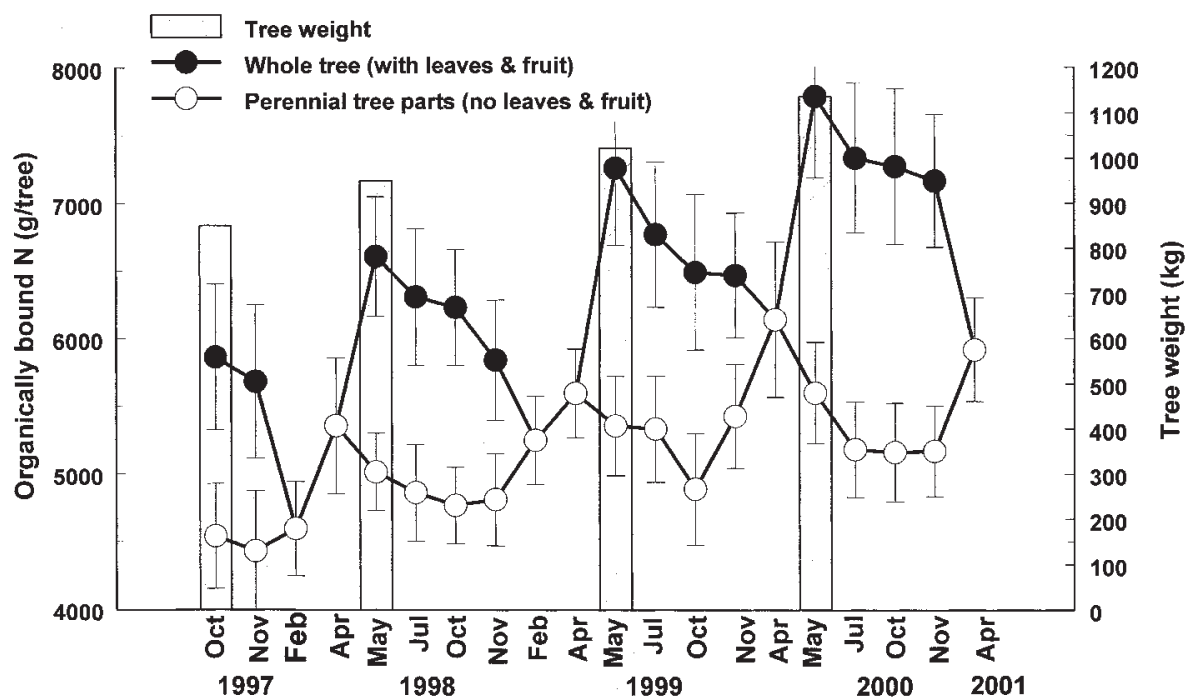

(perennial + annual parts) from April to May. However, $\approx 26 \%$ of the tree's organic $\mathrm{N}$ was allocated to the leaves and flowers in May (Table 3), resulting in a net loss of $\approx 6.5 \%$ in the perennial tree parts (Fig.1). The amount of organic $\mathrm{N}$ in the leaves and flowers during May indicates that both stored $\mathrm{N}$ and newly absorbed $\mathrm{N}$ were preferentially allocated to the annual tree parts. Total organic $\mathrm{N}$ in the perennial tree parts remained relatively static from July through November (Fig. 1), although some reallocation occurred among the various components (Table 3, Fig. 2). However, there was a net loss of organic $\mathrm{N}$ in the whole tree between May and Nov. (Fig.1), that was primarily attributable to reduced leaf $\mathrm{N}$ (Table 3 ).

Pistillate flowers and fruit (involucre + seed) accounted for a relatively small amount

Fig. 1. Seasonal fluctuations in organically bound $\mathrm{N}$ in the perennial tree parts, perennial plus annual tree parts, and total tree weight. Vertical bars are standard deviations.

obtained with the split $\mathrm{N}$ application, but in most cases $\mathrm{N}$ application time did not affect $\mathrm{N}$ gain or loss.

Nitrogen PaRTitioning. Nitrogen application time did not affect organic $\mathrm{N}$ content in the whole tree and rarely in the various components sampled; therefore, data were pooled over treatment to visualize seasonal trends in tree $\mathrm{N}$ content. Patterns of organic $\mathrm{N}$ gains and losses were consistent among years (Fig. 1). Tree weight gains among years were reflected in increased organic $\mathrm{N}$ among years. Organic $\mathrm{N}$ increased each year between November and April in the perennial tree parts and in the whole tree of the tree's total organic $\mathrm{N} ; \approx 0.6 \%$ at anthesis and $4 \%$ at harvest (Table 3, Fig. 2). It appears that most of the $\mathrm{N}$ allocated for fruit development between May and November was reallocated from the leaves (Table 3 ) since the content in the perennial tissue was relatively constant during this period (Fig. 1). At harvest, more N was in the kernel than in the shuck and shell (Table 4). Nitrogen removal at harvest (shell + kernel) varied from none (1998) to 227 $\mathrm{g}$ of $\mathrm{N}$ per tree (2000), mirroring the crop load (Table 5). In 2000, the shucks had an unusually large amount of $\mathrm{N}$ at harvest (Table 4), reflecting an untimely death from an early freeze.

Roots $1 \mathrm{~cm}$ or larger in diameter appeared to be the major organic $\mathrm{N}$ storage organ while trees were dormant (Table 3, Fig. 2 ). Nitrogen accumulated in the large roots from November through April (Fig. 2), apparently from a combination of newly

Table 3. Seasonal changes in organically bound nitrogen content of selected plant parts. Data are pooled over nitrogen treatments.

\begin{tabular}{|c|c|c|c|c|c|c|c|c|c|}
\hline \multirow[b]{3}{*}{ Year } & \multirow[b]{3}{*}{ Month } & \multicolumn{8}{|c|}{ Organically bound $N$ (g/tree) } \\
\hline & & \multicolumn{8}{|c|}{ Plant part } \\
\hline & & $\begin{array}{c}\text { Roots } \\
<1 \mathrm{~cm} \text { diam }\end{array}$ & $\begin{array}{c}\text { Roots } \\
\geq 1 \mathrm{~cm} \text { diam }\end{array}$ & Wood & Bark & $\begin{array}{c}\text { 1-Year-old } \\
\text { branches }\end{array}$ & $\begin{array}{l}\text { Current } \\
\text { season }\end{array}$ & Leaf & Fruit \\
\hline \multirow[t]{2}{*}{1997} & Oct & 510 & 1454 & 1868 & 491 & 119 & 101 & 1067 & 242 \\
\hline & Nov & 588 & $1955^{*}$ & $1051^{*}$ & $589^{*}$ & 111 & $137^{*}$ & 997 & 254 \\
\hline \multirow[t]{6}{*}{1998} & Feb & 663 & 1968 & 1099 & 574 & 127 & 137 & --- & --- \\
\hline & Apr & 715 & 2187 & $1526^{*}$ & 648 & 108 & $171^{*}$ & --- & --- \\
\hline & May & 729 & 2125 & $1007^{*}$ & 784 & $157^{*}$ & $211^{*}$ & 1591 & --- \\
\hline & Jul & 685 & 1907 & 1258 & 710 & 148 & $153^{*}$ & 1446 & --- \\
\hline & Oct & 701 & $1521^{*}$ & $1589^{*}$ & 706 & $131^{*}$ & $118^{*}$ & 1464 & --- \\
\hline & Nov & 716 & 1792 & 1277 & 754 & $168^{*}$ & $102^{*}$ & $1031^{*}$ & --- \\
\hline \multirow[t]{6}{*}{1999} & Feb & 811 & 2001 & $2001^{*}$ & 769 & 181 & $138^{*}$ & --- & --- \\
\hline & Apr & $650^{*}$ & $2384^{*}$ & $1511^{*}$ & 783 & 139 & 126 & --- & --- \\
\hline & May & 793 & 2250 & $937^{*}$ & 861 & $227^{*}$ & $286^{*}$ & 1898 & 68 \\
\hline & Jul & 820 & 2107 & $1278^{*}$ & 809 & $157^{*}$ & $159^{*}$ & $1427^{*}$ & 72 \\
\hline & Oct & $697^{*}$ & 2179 & $926^{*}$ & 777 & 162 & 147 & 1486 & $114^{*}$ \\
\hline & Nov & 748 & 2382 & $1174^{*}$ & 796 & $179^{*}$ & 145 & $896^{*}$ & $143^{*}$ \\
\hline \multirow[t]{5}{*}{2000} & Apr & $927^{*}$ & 2759 & 1221 & 865 & 174 & $192^{*}$ & --- & --- \\
\hline & May & 857 & 2507 & $801^{*}$ & 920 & $234^{*}$ & $278^{*}$ & 2166 & 21 \\
\hline & Jul & 791 & 2073 & $1098^{*}$ & 842 & $176^{*}$ & $200^{*}$ & 2127 & 23 \\
\hline & Oct & 698 & 2219 & 1103 & 819 & 161 & $158^{*}$ & 1760 & $351^{*}$ \\
\hline & Nov & 756 & 2135 & 1152 & 821 & 156 & 148 & 1630 & 364 \\
\hline 2001 & Apr & 785 & $2643^{*}$ & 1170 & 910 & 164 & $244^{*}$ & --- & --- \\
\hline
\end{tabular}

*Means within columns followed by an asterisk are significantly different from the previous mean by fisher's $\mathrm{F}$ test $(P \leq 0.05)$. 


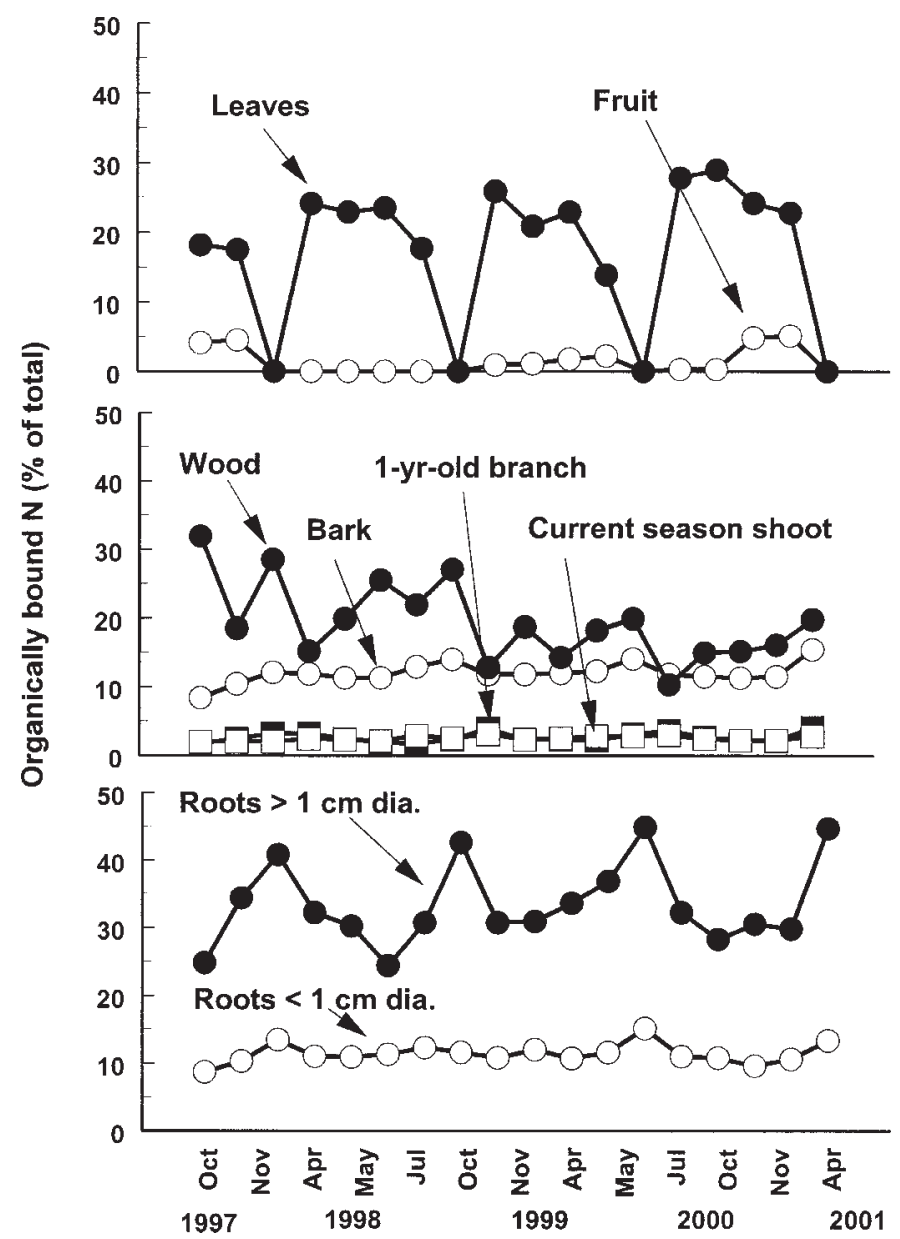

Fig. 2. Seasonal fluctuations in the organically bound $\mathrm{N}$ partitioning in selected tree parts.

Table 4. Organically bound nitrogen content in the shucks, shells and kernels for three years. Data are pooled over nitrogen treatments. There were no fruit in 1998.

\begin{tabular}{lccc}
\hline \hline & \multicolumn{3}{c}{ Organically bound N (g/tree) } \\
\cline { 2 - 4 } Year & Shuck & Shell & Kernel \\
\hline 1997 & $61 \mathrm{~b}^{\mathrm{z}}$ & $17 \mathrm{~b}$ & $177 \mathrm{a}$ \\
1999 & $45 \mathrm{~b}$ & $9 \mathrm{c}$ & $89 \mathrm{~b}$ \\
2000 & $137 \mathrm{a}$ & $25 \mathrm{a}$ & $202 \mathrm{a}$
\end{tabular}

$\overline{{ }^{\mathrm{z}} \text { Means within columns followed by the same letter are not significantly }}$ different by Duncan's multiple range test $(P \leq 0.05)$.

Table 5. The influence of year and nitrogen treatment on leaf nitrogen changes between July or October and fall defoliation.

\begin{tabular}{llll}
\hline \hline $\mathrm{N}$ & \multicolumn{3}{c}{ Leaf N decrease (\%) } \\
\cline { 2 - 4 } treatment & 1998 & 1999 & 2000 \\
\hline July to defoliation & & & \\
$\quad$ Single & 28 & 36 & 21 \\
$\quad$ Split & 30 & 37 & 22 \\
$\quad$ Mean & $29 \mathrm{~b}^{\mathrm{z}}$ & $36 \mathrm{c}$ & $22 \mathrm{a}$ \\
October to defoliation & & & \\
$\quad$ Single & 27 & 41 & 3 \\
$\quad$ Split & 31 & 36 & 8 \\
$\quad$ Mean & $29 \mathrm{~b}$ & $39 \mathrm{c}$ & $6 \mathrm{a}$
\end{tabular}

${ }^{\bar{z}}$ The interaction of year with treatment and treatment main effect were not significant. Mean separation for the year main effect by LSD $(P \leq$ $0.05)$. absorbed $\mathrm{N}$ (Fig. 1) and redistribution of $\mathrm{N}$ from other plant parts (Fig. 2). Nitrogen content and concentration in the small roots were relatively constant during the season, except during April in two of the four years (Tables 2 and 3). The wood appears to serve as a temporary organic $\mathrm{N}$ storage site, since the $\mathrm{N}$ content, concentration and amount relative to other parts fluctuated throughout the season, and much more than in the bark (Tables 2 and 3, Fig 2), an organ reported to serve as a major $\mathrm{N}$ storage organ in other species (Coleman et al., 1992; Wetzel et al., 1989). Although 1-year-old branches and current season shoots contained only a small proportion of the tree's organic N (Fig. 2), N changed rapidly in these plant parts (Tables 2 and 3). Nitrogen concentration and content in the current season shoots were higher in April relative to November, reflecting active translocation of organic $\mathrm{N}$ primarily to the expanding buds. The May sample was taken druing anthesis, following shoot elongation and when most leaf expansion was complete. Organic $\mathrm{N}$ content and concentration in 1 -year-old branches and current season shoots peaked in May, then in most instances declined in July through October. In November, organic N typically continued to decline in the current season shoots, but increased in the 1-year-old branches, perhaps reflecting some $\mathrm{N}$ redistribution from the leaves and current season shoots.

Leaf organic $\mathrm{N}$ declined substantially between July or October and defoliation (Table 6), although a substantial amount of $\mathrm{N}$ was in the leaves when they were killed (Table 3). Nitrogen treatment did not affect $\mathrm{N}$ losses in the leaves, although substantial differences existed among years (Table 6). These discrepancies largely reflect the differences among the growing seasons. In 2000, a freeze killed the leaves $\approx 1$ month earlier than in other years resulting in more $\mathrm{N}$ being retained in the leaves.

Nitrogen treatment did not affect yield, weight per nut or kernel percentage (Table 5). There were substantial differences in yield among years, but yield differences minimally affected total tree $\mathrm{N}$ content (Table 3 and Fig. 1).

\section{Discussion}

One of our objectives was to determine if a $\mathrm{N}$ application split between March and October would reduce alternate bearing by increasing stored $\mathrm{N}$ reserves compared to a single $\mathrm{N}$ application in March. We chose the first week in October for the second part of the application because an earlier Oklahoma study showed that defoliation before 15 Oct. reduced or eliminated production the following year (Hinrichs, 1962), suggesting that this might also be a critical time to maintain adequate $\mathrm{N}$. In prune, $\mathrm{NO}_{3}^{-}$uptake was positively correlated with the presence of leaves in the fall (Weinbaum et al., 1978), and depleted $\mathrm{N}$ reserves caused by

Table 6. The influence of year and nitrogen treatment on yield, nut weight and kernel percentage.

\begin{tabular}{lcccc}
\hline \hline Year & $\begin{array}{c}\mathrm{N} \\
\text { treatment }\end{array}$ & $\begin{array}{c}\text { Yield } \\
(\mathrm{kg} / \text { tree })\end{array}$ & $\begin{array}{c}\text { Nut wt } \\
(\mathrm{g} / \mathrm{nut})\end{array}$ & $\begin{array}{c}\text { Kernel } \\
(\%)\end{array}$ \\
\hline 1997 & Single & $17.1^{\mathrm{z}}$ & 10.1 & 61.12 \\
& Split & 21.1 & 9.8 & 60.96 \\
1999 & Single & 8.8 & 9.4 & 56.27 \\
& Split & 8.8 & 9.2 & 55.79 \\
2000 & Single & 21.1 & 8.2 & 51.41 \\
& Split & 22.9 & 7.6 & 50.22
\end{tabular}

$\overline{{ }^{\mathrm{Z}} \text { Interaction and main effects were not significantly different by fisher's }}$ F test $(P \leq 0.05)$. 
fruiting should create a N demand (Rosecrance et al., 1996; Weinbaum and van Kessel, 1998; Weinbaum et al., 1994a), thus enhancing fall $\mathrm{N}$ absorption. Pecan trees in this area normally retain their foliage until early November and fruit ripen during early to mid October; thus we expected substantial $\mathrm{N}$ absorption between October and defoliation. Results of this study indicated that yield was similar in both $\mathrm{N}$ treatments (Table 5). Similarly, no effect on yield has been observed in three other studies that are in progress with three to five years data that compare a split $\mathrm{N}$ application in March followed by an application in August or October with a single March application (data not published). In addition, we found little evidence suggesting that the split application improved $\mathrm{N}$ absorption compared to the single application (Table 1). Although some $\mathrm{N}$ was absorbed between October and November, $\mathrm{N}$ content in the perennial part of the tree remained relatively static. However, our methods may be inadequate to quantify small amounts of $\mathrm{N}$ absorption, especially if $\mathrm{N}$ is being simultaneously lost from the tree. Nitrogen uptake of pistachio was negligible between harvest and leaf senescence (Rosecrance et al., 1996), similar to the small amount of fall $\mathrm{N}$ absorption we observed in pecan.

The major time of $\mathrm{N}$ accumulation in pecan appeared to be as new leaves, shoots and flowers were developing in the spring (Table 1, Fig. 1). The second highest time of $\mathrm{N}$ accumulation was while trees were dormant. An average of $792 \mathrm{~g}$ of $\mathrm{N}$ were absorbed while dormant and $1540 \mathrm{~g}$ between budbreak and the end of shoot expansion in May. Nitrogen absorption while trees were dormant occurred throughout the winter, since $\mathrm{N}$ absorbed between November and February was 33\% of the amount absorbed between November and April. However, this does suggest that $\mathrm{N}$ absorption is greater during the latter part of dormancy. There were no differences between treatments in the amount of $\mathrm{N}$ absorbed while the trees were dormant, indicating that residual fertilizer $\mathrm{N}$ and native soil $\mathrm{N}$ were sufficient to meet tree demand, regardless of treatment. Nitrogen absorption during dormancy has been reported in apple (Tromp, 1983), peach (Muñoz et al., 1993), and prune (Weinbaum et al., 1978); however, the N uptake during dormancy was typically low compared to other times. Pecan appears to be rather unusual in that $\approx 30 \%$ of the $\mathrm{N}$ absorbed was during dormancy. Our $\mathrm{N}$ estimates are dependent on the accuracy of mass estimates for each tree component. The data strongly support the conclusion that pecan trees absorb $\mathrm{N}$ during dormancy, but we may be overestimating the amount of $\mathrm{N}$ absorbed if our mass estimates are incorrect.

After organic $\mathrm{N}$ content peaked in May there was a gradual loss of $\mathrm{N}$ until November, primarily from the leaves. We are unable to explain the $\mathrm{N}$ losses from the leaves unless leaching of water soluble $\mathrm{N}$ compounds occurred during rain events. Another possible explanation is that $\mathrm{N}$ was being relocated to other areas of the tree, but changes in the $\mathrm{N}$ content of other tree components were below our detection limits.

Nitrogen uptake was not closely related to crop load. For instance, between budbreak (April) and the end of shoot expansion (May) trees absorbed $1249 \mathrm{~g}$ of $\mathrm{N}$ in 1998, a year with very few fruit, $1727 \mathrm{~g}$ in 1999 with a moderate crop, and $1646 \mathrm{~g}$ in 2000 with a very large crop. Nitrogen content in the tree then declined from May to November, indicating that $\mathrm{N}$ losses exceeded any $\mathrm{N}$ absorbed (Fig. 1). It appears that $\mathrm{N}$ absorption occurred during winter and spring, then trees were unable to adjust $\mathrm{N}$ content relative to the crop load as the fruit developed from May through ripening in late October. In contrast, pistachio appeared to adjust N uptake during nut fill based on the demand created by crop load, although the adjustment was not sufficient to prevent depletion of $\mathrm{N}$ reserves (Rosecrance et al., 1996). Substantially more $\mathrm{N}$ is allocated to pistachio fruit than to pecan fruit, and the amount of $\mathrm{N}$ in pecan fruit accounts for a small portion of the $\mathrm{N}$ in the tree (Table 4); thus developing pecan fruit may not create sufficient demand to stimulate $\mathrm{N}$ absorption. Pecan crop load the previous year was also not closely linked to absorbed N. In 1997, trees had a large crop followed by $1249 \mathrm{~g}$ of $\mathrm{N}$ absorbed in 1998. In 1998, the crop was very light with none harvested and $1727 \mathrm{~g}$ were absorbed in 1999. There was a moderate crop in 1999 followed by $1646 \mathrm{~g}$ of $\mathrm{N}$ absorbed in 2000. The fruit accounted for $4 \%, 0 \%$, $2 \%$, and $5 \%$ of the trees' total $\mathrm{N}$ in years 1997 through 2000, respectively.

Nitrogen storage for recycling in walnut (Juglans regia L.) was estimated at $\approx 50 \%$ of the total $\mathrm{N}$ content in the perennial tree parts (Weinbaum and van Kessel, 1998) and from $38 \%$ to $6 \%$ depending on the off- or on-year fruiting for pistachio (Rosecrance et al., 1998). A similar assumption in pecan would indicate that stored $\mathrm{N}$ (highest $\mathrm{N}$ content in perennial parts - lowest $\mathrm{N}$ content in perennial parts; April $\mathrm{N}-$ October $\mathrm{N}$ in perennial parts) in pecan ranged from $11 \%$ to $16 \%$ with an average of $13 \%$. Stored $\mathrm{N}$ was not closely related to either the previous or current season fruit load.

Depletion of $\mathrm{N}$ reserves between April and May in the perennial parts ranged from $240 \mathrm{~g}$ to $542 \mathrm{~g}$ with an average of $375 \mathrm{~g}$. Nitrogen absorbed during this same period ranged from $1248 \mathrm{~g}$ to $1664 \mathrm{~g}$ with an average of $1519 \mathrm{~g}$. The amount of absorbed $\mathrm{N}$ was inversely related to depletion of stored N. This suggests that stored $\mathrm{N}$ was preferentially utilized until depleted, then absorption met the unsatisfied demand if sufficient soil $\mathrm{N}$ was available. Similarly, in other crops stored $\mathrm{N}$ was used for initial growth before significant $\mathrm{N}$ absorption was initiated (Deng et al., 1989a, 1989 b). Because $\mathrm{N}$ allocation to flowers was small relative to leaves in pecan, and fruit do not develop until after May, stored $\mathrm{N}$ is probably not limiting for flower development in orchards with sufficient leaf $\mathrm{N}$ in July of the previous year. However, flower abortion would be likely if trees were $\mathrm{N}$ deficient the previous year resulting in low stored $\mathrm{N}$ reserves (Deng et al., 1991), since early spring vegetative and reproductive growth are competing sinks for stored N (Deng et al., 1989b). In pecan, current season absorbed $\mathrm{N}$ was rapidly transported to developing organs as demonstrated when catkins were labeled with ${ }^{15} \mathrm{~N}$ that was applied $\approx 5$ weeks earlier (Kraimer et al., 2001). However, more $\mathrm{N}$ was allocated to the catkins from stored reserves than from current year $\mathrm{N}$. In our study, we believe that $\mathrm{N}$ was not limited, although July leaf $\mathrm{N}$ concentration appears below standard values, all the compound leaves, including the rachis, on a shoot were used rather than the standard index tissue. Leaf $\mathrm{N}$ based on the standard index tissue was $>2.5 \%$, annually. Pecan fruit development appeared more dependent on current year $\mathrm{N}$ absorption than stored $\mathrm{N}$ reserves, because development occurred after most of the current year $\mathrm{N}$ had been absorbed. Similarly, walnut fruit were highly labeled with $\mathrm{N}$ derived from current year uptake; whereas, flowers were more highly labeled with $\mathrm{N}$ from stored reserves (Deng, 1989a). However, the number of new shoots/branch, initial shoot growth and leaf expansion of pecan were probably highly dependent on stored $\mathrm{N}$ at the beginning of the growing season, and would be competing with flowers for stored N.

Nitrogen from leaves appeared to be the primary source of $\mathrm{N}$ for developing fruit. In pecan, leaf $\mathrm{N}$ was depleted as fruit developed on shoots with fruit, but not if the fruit was removed 
(Sparks, 1977). One striking difference between pecan and several other perennial crops was the small amount of organic $\mathrm{N}$ recovery before leaf death. In pecan, there appeared to be little $\mathrm{N}$ recovered from the leaves since $\mathrm{N}$ content in the perennial parts remained static (Fig. 1). Our methods may have been inadequate to detect $\mathrm{N}$ redistribution from the leaves to perennial parts, but the magnitude of the change in leaf N content, $25 \%$ of the total tree $\mathrm{N}$ in May and $17 \%$ in November, suggests this is not likely. However, in other species, $\mathrm{N}$ recovered from the leaves represented a major part of the stored N pool (Muñoz et al., 1993; Rosecrance et al., 1998; Weinbaum et al., 1994a).

Our data suggest that $\mathrm{N}$ should be applied before budbreak since absorption apparently takes place during dormancy followed by rapid $\mathrm{N}$ absorption during shoot and leaf development. A split $\mathrm{N}$ application is justifiable on certain pecan sites that are subjected to spring flooding or water saturated soils that can cause denitrification and $\mathrm{N}$ leaching. However, the second application should be during the spring rather than the fall. Frequently, growers apply a second $\mathrm{N}$ application in June, after fruit set, with the $\mathrm{N}$ rate adjusted based on crop load. Our data indicate that the second application should be before fruit set, while the shoots and leaves are rapidly expanding. Delaying until after fruit set would probably decrease $\mathrm{N}$ uptake efficiency, although $\mathrm{N}$ absorption should occur relative to demand. The effect of crop load on the tree's $\mathrm{N}$ demand for $\mathrm{N}$ is small; therefore, adjustment based on crop load should have little impact on demand and absorption efficiency. Large pecan crops may deplete the subsequent year's tree $\mathrm{N}$ reserves if available $\mathrm{N}$ is low (Hunter and Hammar, 1957), but if adequately supplied with N, crop load appears to minimally impact the subsequent year's leaf $\mathrm{N}$ concentration (Smith et al., 1985; Worley, 1974).

\section{Literature Cited}

Brown, P.H., S.A. Weinbaum, and G.A. Picchioni. 1995. Alternate bearing influences annual nutrient consumption and the total nutrient content of mature pistachio trees. Trees Structure and Function 9:158 164.

Coleman, G.D., T.H. Chen, and L.H. Fuchigami. 1992. Complementary DNA cloning of poplar bark storage proteins and control of its expression by photoperiod. Plant Physiol. 98:687-693.

Cooper, H.D. and D.T. Clarkson. 1989. Cycling of amino-nitrogen and other nutrients between shoots and roots in cereals-A possible mechanism integrating shoot and root in the regulation of nutrient uptake. J. Expt. Bot. 40:753-762.

Delap, A.V. 1967. The effect of supplying nitrate at different seasons on the growth, blossoming and nitrogen content of young apple trees in sand culture. J. Hort. Sci. 42:149-167.

Deng, X., S.A. Weinbaum, and T.M. DeJong. 1989a. Use of labeled nitrogen to monitor transition in nitrogen dependence of storage to current-year uptake in mature walnut trees. Trees 3:11-16.

Deng, X., S.A. Weinbaum, T.M. DeJong, and T.T. Muraoka. 1989b. Utilization of nitrogen from storage and current-year uptake in walnut spurs during the spring flush of growth. Physiol. Plant. 75:492-498.

Deng, X., S.A. Weinbaum, T.M. DeJong, and T.T. Muraoka. 1991. Pistillate flower abortion in 'Serr' walnut associated with reduced carbohydrate and nitrogen concentrations in wood and xylem sap. J. Amer. Soc. Hort. Sci. 116:291-296.

Golomb, A. and E.E. Goldschmidt. 1987. Mineral nutrient balance and impairment of the nitrate-reducing system in alternate-bearing 'Wilking' mandarin trees. J. Amer. Soc. Hort. Sci. 112: 397-401.

Hill-Cottingham, D.G. 1963. Effect of the time of application of fertilizer nitrogen on the growth, flowering and fruiting of maiden apple trees grown in sand culture. J. Hort. Sci. 38:242-251.

Hill-Cottingham, D.G. and R.R. Williams. 1967. Effect of time of application of fertilizer nitrogen on the growth, flower development and fruit set of maiden apple trees, var. Lord Lambourne, and the distribution of total nitrogen within the trees. J. Hort. Sci.42:319-338.

Hinrichs, H.A. 1962. Pecan industry and some research developments in Oklahoma. N. Nut Growers' Assn. 58:80-85.

Horowitz, W. (ed.). 1980. Official methods of analysis of the association of analytical chemists. 13 ed. Assn. Offic. Anal. Chem., Wash., D.C. p.15, section 2058.

Hunter, J.H. and H.E. Hammar. 1957. Variation in composition of pecan leaves. Better Crops with Plant Food 41(2):18-25.

Hunter, J.H. and R.D. Lewis. 1942. Influence of fertilizer and time of its application on growth, yield, and quality of pecans. J. Amer Soc. Agron. 34:175-187.

Imsande, J. and B. Touraine. 1994. N demand and the regulation of nitrate uptake. Plant Physiol. 105:3-7.

King, W.W. and R.L. Schnell. 1972. Biomass estimates of black oak tree components. Tenn. Valley Auth. Div. For., Fisheries, Wildlife Mgt. Tech. Note B1.

Kraimer, R.A., W.C. Lindemann, and E.A. Herrera. 2001. Distribution of ${ }^{15} \mathrm{~N}$-labeled fertilizer applied to pecan: A case study. HortScience 36:308-312.

Lee, R.B., J.V. Purves, R.G. Ratcliffe, and L.R. Saker. 1992. Nitrogen assimilation and the control of ammonium and nitrate absorption by maize roots. J. Expt. Bot. 43:1385-1396.

Lockwood, D.W. and D. Sparks. 1978. Translocation of ${ }^{14} \mathrm{C}$ in 'Stuart' pecan in the spring following assimilation of ${ }^{14} \mathrm{CO}_{2}$ during the previous growing season. J. Amer. Soc. Hort. Sci. 103:38-45.

Monselise, S.P. and E.E. Goldschmidt. 1982. Alternate bearing in fruit trees. Hort. Rev. 4:128-173.

Muñoz, N., J. Guerri, F. Legaz, and E. Primo-Millo. 1993. Seasonal uptake of ${ }^{15} \mathrm{~N}$-nitrate and distribution of absorbed nitrogen in peach trees. Plant and Soil 150:263-269.

Rosecrance, R.C., S.A. Weinbaum, and P.H. Brown. 1996. Assessment of nitrogen, phosphorus, and potassium uptake capacity and root growth in mature alternate-bearing pistachio (Pistacia vera) trees. Tree Physiol. 16:949-956.

Rosecrance, R.C., S.A. Weinbaum, and P.H. Brown. 1998. Alternate bearing affects nitrogen, phosphorus, potassium and starch storage pools in mature pistachio trees. Ann. Bot. 82:463-470.

Smith, C.L. and J.G. Waugh. 1938. Seasonal variations in the carbohydrate and nitrogen content of roots of bearing pecan trees. J. Agr. Res. 57:449-460.

Smith, M.W., P.L. Ager, and D.S.W. Endicott. 1985. Effect of nitrogen and potassium on yield, growth and leaf elemental concentration of pecan. J. Amer. Soc. Hort. Sci. 110:446-450.

Smith, M.W., B. Cheary, and B. Carroll. 1995. Time of nitrogen application and phosphorus effects on growth, yield, and fruit quality of pecan. HortScience 30:532-534.

Smith, M.W. and B.D. McCraw. 1998. Weed control in pecans, apples and peaches. Okla. Coop. Ext. Ser. Curr. Rpt. CR-6242.

Sparks, D. 1977. Effects of fruiting on scorch, premature defoliation, and nutrient status of 'Chickasaw' pecan leaves. J. Amer. Soc. Hort. Sci. 102:669-673.

Taylor, B.K., B. van den Ende, and R.L. Canterford. 1975. Effects of rate and timing of nitrogen applications on the performance and chemical composition of young pear trees, cv Williams' Bon Chretien. J. Hort. Sci. 50:29-40.

Tromp, J. 1983. Nutrient reserves in roots of fruit trees, in particular carbohydrates and nitrogen. Plant and Soil 71:401-413.

von Broembsen, S., P. Mulder, and B.D. McCraw. 1999. Commercial pecan insect and disease control-2000. Okla. Coop. Ext. Ser. Curr. Rpt. CR-6209.

Weinbaum, S.A., R.S. Johnson, and T.M. DeJong. 1992. Causes and consequences of overfertilization in orchards. HortTechnology 2:112121.

Weinbaum, S. and C. van Kessel. 1998. Quantitative estimates of uptake and internal cycling of ${ }^{14} \mathrm{~N}$-labeled fertilizer in mature walnut trees. Tree Physiol. 18:795-801. 
Weinbaum, S.A., M.L. Merwin, and T.T. Muraoka. 1978. Seasonal variation in nitrate uptake efficiency and distribution of absorbed nitrogen in non-bearing prune trees. J. Amer. Soc. Hort. Sci. 103:516-519.

Weinbaum, S.A., G.A. Picchioni, T.T. Maraoka, P.H. Brown, and L. Ferguson. 1994a. Nitrogen usage, accumulations of carbon and nitrogen reserves, and the capacity for labeled fertilizer nitrogen and boron uptake varies during the alternate-bearing cycle in pistachio. J. Amer. Soc. Hort. Sci. 119:24-31.

Weinbaum, S.A., F.J.A. Niederhoizer, S. Ponchner, R.C. Rosecrance, R.M. Carlson, A.C. Whittlesey, and T.T. Muraoka. 1994b. Nutrient uptake by cropping and defruited field-grown 'French' prune trees. J. Amer. Soc. Hort. Sci. 119:925-930.

Wetzel, S., C. Demmers, and J.S. Greenwood. 1989. Seasonally fluctuating bark proteins are a potential form of nitrogen storage in three temperate hardwoods. Planta 178:275-281.

Wetzstein, H.Y. and D. Sparks. 1983. The morphology of pistillate flower differentiation in pecan. J. Amer. Soc. Hort. Sci. 108:997-1003

Williams, R.R. 1963. The effect of nitrogen on the self-fruitfulness of certain varieties of cider apples. J. Hort. Sci. 38:52-60.

Williams, R.R. 1965. The effect of summer nitrogen applications on the quality of apple blossom. J. Hort. Sci. 40:31-41.

Wood, B.W. 1988. Fruiting affects photosynthesis and senescence of pecan leaves. J. Amer. Soc. Hort. Sci. 113:432-436.
Wood, B.W. 1989. Pecan production responds to root carbohydrates and rootstock. J. Amer. Soc. Hort. Sci. 114:223-228.

Wood, B.W. 1991. Alternate bearing of pecan, p. 180-190. In: B.W. Wood and J.A. Payne (eds.). Pecan husbandry: Challenges and opportunities. 1st Natl. Pecan Wkshp. Proc., U.S. Dept. of Agr., Agr. Res. Serv. ARS-96.

Wood, B.W. 1993. Production characteristics of the United States pecan industry. J. Amer. Soc. Hort. Sci. 118:538-545.

Wood, B.W. 1995. Relationship of reproductive and vegetative characteristics of pecan to previous-season fruit development and postripening foliation period. J. Amer. Soc. Hort. Sci. 120:635-642.

Worley, R.E. 1974. Effect of N, P, K, and lime on yield, nut quality, tree growth, and leaf analysis of pecan (Carya illinoensis W.). J. Amer. Soc. Hort Sci. 99:49-57.

Worley, R.E. 1979a. Pecan yield, quality, nutlet set, and spring growth as a response to time of fall defoliation. J. Amer. Soc. Hort. Sci. 104:192-194.

Worley, R.E. 1979b. Fall defoliation date and seasonal carbohydrate concentration of pecan wood tissue. J. Amer. Soc. Hort. Sci. 104:195199.

Worthington, J.W. and L.A. Stein. 1993. Water management, p. V-9-V20. In: G.R. McEachern and L.A. Stein (eds.). Texas pecan handbook. Texas Agr. Ext. Serv. TAEX Hort. Hdbk. 105. 